Arkhais, Vol. 06 No. 2 Jufi - Desember 2015

\title{
KEEFEKTIFAN KALIMAT PADA SKRIPSI MAHASISWA FAKULTAS ILMU PENDIDIKAN UNIVERSITAS NEGERI JAKARTA
}

\author{
Nurul Azizah
}

\begin{abstract}
Abstrak.Penelitian ini bertujuan untuk mendeskripsikan keefektifan kalimat pada skripsi mahasiswa FIP UNJ dengan menggunakan aspek kalimat efektif, seperti aspek kelugasan, kebernalaran, kepaduan, dan kegramatikalan kalimat. Penelitian ini dilaksanakan di Jakarta pada bulan Maret hingga Juni di semester genap 2014. Fokus penelitian ini adalah aspek kegramatikalan dalam membentuk kalimat efektif. Objek penelitian ini adalah skripsi mahasiswa Jurusan PGSD Fakultas Ilmu Pendidikan UNJ pada tahun 2012. Metode penelitian ini adalah deskriptif kualitatif. Hasil dari penelitian ini telah membuktikan bahwa kalimat efektif pada skripsi mahasiswa dihasilkan dengan terpenuhinya syarat kegramatikalan atau kaidah ketatabahasaan. Berdasarkan hasil penelitian, ditemukan 114 kalimat yang efektif dan 51 kalimat yang tidak efektif dari 165 data yang diteliti. Dalam kalimat yang efektif tersebut ditemukan aspek kalimat efektif yang paling banyak terpenuhi ialah aspek kegramatikalan dalam pembentukan kata dengan afiksasi, diikuti oleh aspek kegramatikalan dalam penyusunan kalimat berdasarkan fungsi kalimatnya. Hal itu menunjukkan bahwa aspek kegramatikalan memegang peranan yang sangat penting dalam pembentukan kalimat efektif pada skripsi mahasiswa. Sementara itu pada kalimat yang tidak efektif ditemukan aspek kepaduan dan kebernalaran sebagai dua aspek tertinggi yang tidak terpenuhi. Hal itu menunjukkan bahwa pemahaman mahasiswa dalam aspek kepaduan dan kebernalaran masih lemah.
\end{abstract}

Kata Kunci: Kalimat, Keefektifan Kalimat, Skripsi Mahasiswa

\section{PENDAHULUAN}

Bahasa merupakan alat untuk berpikir dengan pertolongan sistem lambanglambang bunyi. Sistem lambang (bahasa) yang diciptakan itu tentunya harus dapat mewakili pikiran, gagasan, atau maksud yang hendak diungkapkan. Suatu bahasa tentunya memiliki kaidah yang harus ditaati pemakainya agar tidak terjadi kesalahan dalam penafsirannya. Mahasiswa sebagai orang terpelajar telah mendapat kesempatan seluasluasnya untuk mempelajari penggunaaan bahasa dalam berkomunikasi. Hal ini memiliki kaitan bahwa mereka harus mampu membedakan penggunaan bahasa sesuai dengan ragamnya. Penggunaan bahasa yang baik adalah tepat dalam memilih ragam bahasa yang sesuai dengan kebutuhan komunikasi (Sugono, 2009:21). Salah satu ragam bahasa ialah ragam bahasa ilmiah. Ragam ilmiah digunakan untuk melaporkan hasil kegiatan ilmiah, yang dilakukan dalam suatu penelitian ilmiah (Char, 2011:3), termasuk di dalamnya skripsi yang merupakan tugas mahasiswa untuk menyelesaikan studinya di perguruan tinggi. Laporan penelitian ilmiah, seperti skripsi, merupakan karya ilmiah yang menjadi salah satu persyaratan akhir untuk menjadi seorang sarjana. Istilah karya ilmiah mengacu pada karya tulis yang penyusunannya didasarkan pada kajian ilmiah. Karya ilmiah tentunya menggunakan ragam bahasa ilmiah yang memiliki aturan tersendiri.

Karya ilmiah berisi gagasan-gagasan yang hendak disampaikan penulis kepada pembaca. Gagasan-gagasan yang bersifat ilmiah ini harus sampai kepada pembaca secara tepat. Artinya, gagasan yang ingin disampaikan oleh penulis dapat diterima secara tepat 
olah pembaca. Oleh karena itu, kalimat yang digunakan penulis dalam menyampaikan gagasannya haruslah terstruktur dengan baik. Kalimat yang baik haruslah memenuhi persyaratan gramatikal. Kegramatikalan ini merupakan salah satu hal yang sangat mempengaruhi apakah gagasan penulis dapat terekspresikan dengan baik, jelas, dan kuat . Jika wujud kalimat yang dilahirkan itu tidak baik susunannya, artinya pikiran yang menghasilkan bahasa itu pun kacau, maksudnya logika tidak berjalan dengan baik. Hal tersebut mengungkapkan bahwa kegramatialan menjadi kunci terbentuknya kalimat yang baik agar tersampaikan secara tepat. Pendapat yang dikemukakan dalam skripsi didukung oleh data dan fakta, baik berdasarkan penelitian langsung (observasi lapangan) maupun penelitian tidak langsung (Arifin, 2006:3). Hasil penelitian itu disampaikan melalui media bahasa. Dalam penyampaian itu tentunya diharapkan tidak terjadi kesalahan tafsir. Oleh karena itu, harus ada kesamaan penalaran penulis dan interpretasi pembacanya. Hal itu diwujudkan melalui penggunaan kalimat yang efektif dalam menyampaikan gagasan.

Penelitian mengenai keefektifan kalimat telah banyak dilakukan, tetapi kebanyakan penelitian sebelumnya mengambil objek tulisan siswa. Penelitian yang relevan dengan penelitian ini salah satunya ialah skripsi karya Rusmanah pada tahun 2002 yang berjudul Analisis Penggunaan Kalimat Efektif dalam Teks Dakwah Siswa Kelas III Madrasah Aliyah Di Tangerang. Penelitian tersebut difokuskan pada kalimat efektif dengan kriteriakesepadanan, paralelisme, penekanan, kehematan, dan kelogisan. Hasil penelitian tersebut adalah kalimat siswa paling banyak memiliki ciri penekanan dan kesepadanan, sedangkan ciri yang paling sedikit adalah ciri paralelisme dan kehematan. Berbeda dengan penelitian sebelumnya, penelitian ini menganalisis keefektifan kalimat pada karya ilmiah berupa skripsi. Keefektifan kalimat itu dilihat dari terpenuhinya aspek kegramatikalan. Kegramatikalan ini menjadi fokus penelitian di samping aspek kalimat efektif lain, yaitu kelugasan, kebernalaran, dan kepaduan kalimat. Berdasarkan penjabaran tersebut, dapat dirumuskan masalah penelitian yakni, bagaimana keefektifan kalimat pada skripsi mahasiswa Fakultas Ilmu Pendidikan Universitas Negeri Jakarta? Tinjauan pustaka dalam penelitian ini dimulai dari teori kalimat efektif dan dilanjutkan dengan teori aspek-aspek kalimat efektif, yaitu aspek kelugasan, kebernalran, kepaduan, serta kegramatikalan.

Menurut Parera dalam Jalal (2011:95), kalimat dikatakan efektif apabila bentuk kalimat dengan sadar dan sengaja disusun untuk mencapai daya informasi yang tepat dan baik. Kalimat efektif menurut Parera tersebut lebih menekankan pada tersampaikannya informasi dengan tepat. Oleh karena itu, kalimat efektif adalah kalimat yang dapat menyampaikan "pesan" kepada pembaca persis seperti yang ingin disampaikan penulis (Chaer, 2011:63). Pengertian ini mendukung pengertian kalimat efektif sebelumnya, yaitu mengenai penyampaian pesan atau informasi kepada pembaca sesuai yang ingin disampaiakan penulis. Dalam Buku Praktis Bahasa Indonesia (Sugono dkk, 2008:91) dikatakan bahwa "kalimat efektif adalah kalimat yang dapat menggunakan gagasan pemakainya secara tepat dan dapat dipahami secara tepat pula". Pengertian ini menjelaskan bahwa poin penting dalam hakikat kalimat efektif adalah sampainya gagasan secara tepat. Pengertian lain dijelaskan oleh Indriati dalam Sukarmin (2002:8) sebagai berikut.

Sebuah tulisan dikatakan efektif apabila tulisan tersebut mempunyai ciri-ciri singkat, jelas, tepat, aliran logika lancar, dan koheren. Singkat dalam arti tidak perlu menambahkan hal-hal di luar isi pokok tulisan dan mengulang-ulang hal yang sudah dijelaskan (redundant). Jelas (clarity) dalam arti tidak bermakna ganda (ambiguous). Tepat (precise) dalam arti pemilihan kosakata harus tepat menggambarkan yang dimaksud penulis. Aliran logika (logical flow) lancar dalam arti paparan ide pokok didukung oleh penjelasan dan kesimpulan. Dengan demikian, seluruh bagian tulisan merupakan kesatuan yang saling berhubungan (coherence). Penyampaian informasi kepada pembaca menurut 
Indriati dapat sampai apabila kalimat memenuhi beberapa ciri, yaitu disampaikan dengan singkat, jelas, tepat, tidak bermakna ganda, memiliki aliran logika yang lancar, serta saling membentuk kesatuan. Berdasarkan ciri itu, terbentuklah kalimat yeng efektif sehingga dapat menyampaikan informasi dengan baik. Dengan demikian, dapat disimpulkan bahwa kalimat efektif adalah kalimat yang disusun secara singkat, jelas, tepat, dan koheren dengan aliran logika yang lancar untuk mencapai daya informasi yang tepat dan baik sehingga informasi yang disampaikan kepada pembaca persis seperti yang ingin disampaikan penulis. Dalam mendukung kalimat efektif itu, ada beberapa aspek yang perlu dipenuhi sebagai berikut.

\section{Kelugasan}

Kalimat dalam tulisan ilmiah yang efektif haruslah bersifat lugas. Lugas adalah mengenai hal-hal yang pokok atau yang perlu-perlu saja, bersifat seperti apa adanya. Menurut Dendy Sugono, dalam artikelnya mengenai kaidah bahasa ragam ilmiah, kalimat yang lugas berarti bahwa pernyataan-pernyataan yang disampaikan tidak menimbulkan interpretasi ganda atau tidak rancu (Sugono, 2012:5). Pengertian ini menegaskan pada interpretasi yang diterima pembaca, yaitu tidak menimbulkan lebih dari satu interpretasi. Hal itu menunjukkan bahwa kalimat yang bersifat lugas adalah kalimat yang disampaikan secara apa adanya dan hanya berisi hal-hal yang pokok atau yang perlu, tidak bertele-tele, serta memiliki satu makna. Penjabaran di atas menjelaskan bahwa kelugasan terdiri atas lima ciri, yaitu apa adanya, hemat, tidak bermakna kias dan ambigu, serta bernalar. Pengertian ini sejalan dengan pengertian sebelumnya yang menyatakan bahwa kelugasan adalah penyampaian klimat yang apa adanya, berisi hal pokok, serta tidak menimbulkan makna kias maupun makna ganda (ambiguitas). Dengan demikian, yang dimaksud dengan kalimat yang lugas adalah kalimat yang hemat, apa adanya, hanya berisikan hal-hal yang pokok dan perlu, tidak berbunga-bunga atau berlebihan sehingga mudah dipahami, tidak menimbulkan makna kias, dan makna ganda.

\section{Kebernalaran}

Sebuah kalimat harus bernalar maksudnya dapat diterima akal atau logika (Chaer,2011:44). Kalimat yang dapat diterima logika artinya kalimat ini logis. Keefektifan kalimatdidukung oleh jalan pikiran yang logis, sehingga dapat dipahami dengan mudah, cepat, dan tepat serta tidak menimbulkan salah paham (Soedjito, 1986:8). Pengertian tersebut menjelaskan bahwa kebernalaran kalimat mendukung sampainya informasi secara tepat. Kebernalaran atau kelogisan kalimat sangat membantu untuk mempermudah penyampaian gagasan kepada pembaca. Kalimat yang tidak masuk akal dapat membuat pembaca kesulitan dalam menafsirkan gagasan. Menurut Chaer (2011:44), sebuah kalimat menjadi tidak nalar atau tidak masuk akal biasanya bersumber pada empat hal, yaitu kesalahan dalam (1) menarik kesimpulan umum (induktif), (2) menarik kesimpulan khusus (deduktif), (3) menarik persamaan (analogi), dan (4) memberi alasan (argumen). Berdasarkan pendapat tersebut, kebernalaran kalimat bergantung pada cara penulis membuat simpulan, beranalogi, serta berargumen dalam tulisannya. Berdasarkan penjabaran di atas, dapat dikatakan bahwa kebernalaran kalimat berasal dari jalan pikiran penulis yang logis dalam menghubungkan tiap unsur dalam dan luar kalimat, menarik simpulan, beranalogi, serta berargumen dalam menyampaikan maksud dengan logis, sehingga dapat dipahami dengan mudah, cepat, dan tepat, serta tidak menimbulkan salah paham.

\section{Kepaduan}

Kepaduan atau koherensi ialah kesatuan antara bagian-bagian yang ada, serta saling terkait, baik dalam hubungan gramatikal maupun dalam hubungan semantisnya (Semi, 
2003:155). Pengertian itu menjelaskan bahwa padunya kalimat terbentuk atas padunya setiap unsur secara gramatik dan semantik. Kepaduan ini dijelaskan dalam buku PembinaanKemampuan Menulis Bahasa Indonesia sebagai kesepadanan, yaitu kemampuan strukturbahasa dalam mendukung gagasan atau konsep yang merupan kepaduan pikiran (Akhdiah dkk, 1991, 117). Hal itu menjelaskan bahwa kepaduan ini berkaitan dengan struktur kalimat. Pengertian menggenai kepaduan lebih lanjut dijelaskan oleh Soedjito (1986:17) bahwa tidak padunya kalimat dapat disebabkan oleh tidak tepatnya posisi unsur-unsur kalimat itu. Dengan demikian, dapat disimpulkan bahwa kepaduan atau koherensi dalam sebuah kalimat adalah kesatuan tiap unsur-unsurnya sehingga membentuk hubungan gramatikal dan semantis dengan memperhatikan sruktur kalimatnya.

\section{Kegramatikalan}

Sebuah kalimat efektif merupakan kalimat yang memenuhi kaidah ketatabahasaan (gramatik), pemilihan kata, dan kaidah ejaan (Sugono, 2012:5). Oleh karena itu, kalimat dapat ditentukan keefektifannya dengan melihat struktur atau susunan gramatikalnya. Kegramatikalan suatu kalimat dapat ditinjau dari pembentukan kata dan penyusunan kalimat. Pembentukan kata yang gramatik berkenaan dengan afiksasi dan reduplikasi. Afiksasi memiliki beberapa bentuk yang perlu dicermati agar kata yang dibentuk sesuai kaidah ketatabahasaan sehingga terjaga keefektifannya. Afiks gabung ini sering kali menyebabkan redundansi (mubazir) seperti pada kata mempertinggikan, memperjelaskan, memperingatkan,mempersatukan dan sebagai-nya. Imbuhan kan- pada kata mempertinggikan dan memperjelas-kan, serta imbuhan per- pada kata memperingatkan dan memper-satukan tidakperlu (redundansi). Redundansi menyebabkan ke-rumitan pada sebuah kata sehingga kata tersebut menjadi tidak efektif. Selain afiksasi, masalah kegramatikalan yang menentukan keefektifan sebuah kalimat juga menyangkut reduplikasi atau kata ulang. Masalah yang terjadi pada pembentukann kata ulang menyebabkan kalimat semakin panjang dan tidak efektif (Santoso, 1990:65-68). Selain pembentukan kata, kegramatikalan juga mencakup penyusunan kalimat. Kalimat tersusun atas unsurunsur atau konstruksi yang lengkap, yaitu subjek sebagai unsur yang dibicarakan dan predikat sebagai unsur yang menjelaskan apa yang dilakukan atau dialami subjek. Kedua unsur ini merupakan unsur wajib. Adapun unsur lain yaitu objek sebagai unsur yang menjadi sasaran; pelangkap sebagai unsur yang menjelaskan makna pada predikat; dan keterangan. Unsur-unsur kalimat itu harus jelas dan lengkap

Salah satu persyaratan struktural yang membangun sebuah kalimat adalah unsur fungsionalnya. Unsur fungsional menurut Santoso (1990:143) adalah "fungsi-fungsi tertentu dalam suatu kalimat yang diduduki oleh kata atau kelompok kata, yang dibedakan atas unsur inti dan unsur tambahan." Unsur utama suatu kalimat adalah subjek dan predikat, sedangkan unsur tambahan adalah objek dan keterangan. Setiap jenis kalimat memiliki syarat minimal yang harus dipenuhi, misalnya kalimat transitif memiliki syarat minimal subjek, predikat, dan objek, kemudian kalimat intransitif dengan syarat minimalnya berupa subjek dan predikat. Demi keefisienan, orang menggabungkan beberapa pernyataan dalam satu kalimat sehingga lahirlah struktur kalimat yang di dalamnya terdapat beberapa kalimat dasar yang disebut sebagai kalimat majemuk (Sugono, 2009:141). Dalam menggabungkan unsur-unsur atau pernyataan-pernyataan tersebut, diperlukan kata hubung agar kalimat tersebut membentuk kesatuan. Kata hubung itu dinamakan konjungsi. Konjungsi mempunyai peran yang sangat penting dalam kalimat majemuk, yaitu menyatakan hubungan antarkalimat dasar di dalam kalimat majemuk. Konjungsi inilah yang membedakan struktur kalimat majemuk bertingkat dari kalimat majemuk setara. 
Struktur kalimat setara dan bertingkat itu dihubungkan dengan konjungsi koordinatif dan subordinatif. Konjungsi dengan hubungan koordinasi menghubungkan dua struktur yang memunyai kedudukan yang sama (setara), sedangkan hubungan subordinatif menghubungkan dua struktur atau lebih yang menjadikan salah satu unsurnya sebagai bagian dari struktur yang lain (Alwi dkk, 2003:386-388). Adapun konjungsi yang menyatakan hubungan koordinasi (setara) diantaranya; dan, tetapi, atau, lalu, sedangkan, dsb. Konjungsi yang menyatakan hubungan subordinasi (bertingkat) di antaranya; ketika, karena, supaya,meskipun, jika, dan sehingga (Sugono, 2009:153). Selain hubungan gramatik di atas, ada pun hubungan makna yang timbul antarstruktur dalam kalimat (Ramlan, 1986:55). Hubungan itu ditandai oleh kata penghubung yang dibagi ke dalam 18 jenis hubungan makna, yaitu hubungan aditif (gabungan), pertentangan, disjungtif (pilihan), temporal (waktu), final (tujuan), sebab (kausal), akibat (konsekutif), syarat (kondisional), tak bersyarat, perbandingan, korelatif, penegas, penjelas, pembenaran (konsesif), urutan, pembatasan, penanda, dan situasi.

\section{METODOLOGI PENELITIAN}

Tujuan penelitian ini adalah untuk mengetahui bagaimana keefektifan kalimat pada skripsi mahasiswa Fakultas Ilmu Pendidikan UNJ ditinjau dari aspek kalimat efektif berupa kelugasan, kebernalaran, kepaduan, dan kegramatikalan. Penelitian ini tergolong penelitian kajian pustaka. Maka, penelitian ini tidak dibatasi tempat. Penelitian ini dilakukan pada Maret sampai dengan Juni 2014. Berdasarkan jangkauan waktu, penelitian ini tergolong penelitian sinkronis. Objek atau korpus pada penelitian ini adalah skripsi mahasiswa Fakultas Ilmu Pendidikan UNJ jurusan Pendidikan Guru Sekolah Dasar pada tahun 2012. Dari 91 populasi skripsi diambil 15\% dari populasi itu sebagai sampel karena jenis data yang terbilang homogen. Setelah dilakukan penghitungan $15 \%$ dari jumlah popilasi itu, didapat sebanyak 14 skripsi untuk dianalisis. Penelitian ini difokuskan pada aspek kegramatikalan dalam membangun kalimat efektif pada skripsi mahasiswa FIP UNJ. Metode penelitian yang akan digunakan dalam penelitian ini adalah metode kualitatif deskriptif dengan teknik analisis isi. Instrumen penelitian yang digunakan dalam penelitian ini adalah peneliti sendiri dibantu dengan tabel analisis kerja yang dirumuskan dari teori.

\section{HASIL DAN PEMBAHASAN}

Berdasarkan penelitian yang telah dilakukan terhadap skripsi mahasiswa PGSD FIPUNJ tahun 2012 yang telah direduksi hingga diperoleh data sebanyak 165 kalimat, terdapat114 kalimat yang efektif dan 51 kalimat yang tidak efektif. Dari 114 kalimat yang efektif,jumlah aspek-aspek kalimat efektif yang terpenuhi berdasarkan hasil analisis dapat dilihatpada tabel berikut ini.

Tabel 4.2 Rekapitulasi Hasil Analisis pada Kalimat yang Efektif

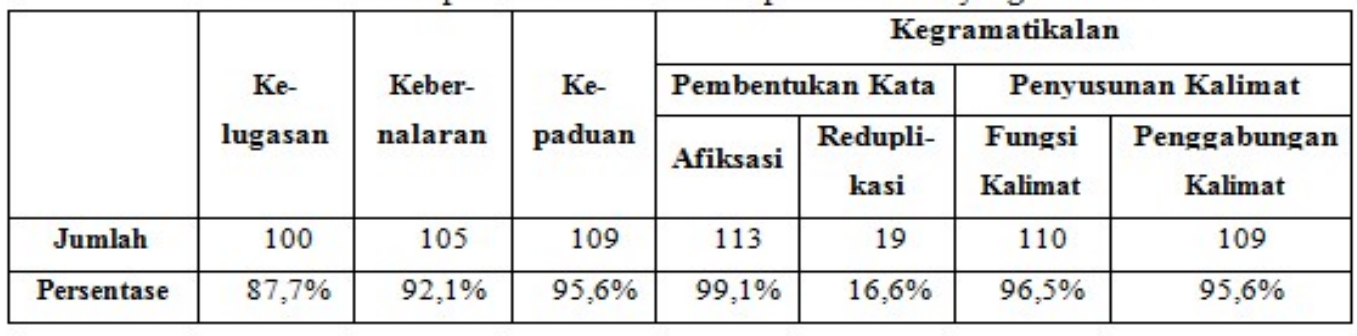

Berdasarkan tabel di atas, dapat dilihat bahwa dari sejumlah 114 kalimat yang efektif, terdapat 100 kalimat yang memenuhi aspek kelugasan (87,7\%), 105 kalimat yang memenuhi aspek kebernalaran $(92,1 \%)$, serta 109 kalimat yang memenuhi aspek kepaduan $(95,6 \%)$. Sementara itu, berdasarkan aspek kegramatikalan dari segi pembentukan 
kalimatnya, diperoleh 113 kalimat dengan pembentukan afiksasi yang baik $(99,1 \%)$ dan 19 kalimat dengan pembentukan reduplikasi yang baik (96,5\%). Kemudian, berdasarkan aspek kegramatikalan dari segi penyusunan kalimatnya, terdapat 110 kalimat dengan penyusunan fungsi yang baik $(96,5 \%)$ dari 109 kalimat dengan penggabungan kalimat yang baik $(95,6 \%)$. Selanjutnya, dari 51 kalimat yang tidak efektif, jumlah aspek-aspek kalimat efektif yang tidak terpenuhi berdasarkan hasil analisis dapat dilihat pada tabel berikut ini.

Tabel 4.3 Rekapitulasi Hasil Analisis pada Kalimat yang Tidak Efektif

\begin{tabular}{|c|c|c|c|c|c|c|c|}
\hline & \multirow{2}{*}{\begin{tabular}{c} 
Ke- \\
\cline { 5 - 7 }
\end{tabular}} & \multirow{2}{*}{$\begin{array}{c}\text { Keber- } \\
\text { Lugasan }\end{array}$} & \multirow{2}{*}{$\begin{array}{c}\text { Ke- } \\
\text { nalaran }\end{array}$} & paduan & & \multicolumn{4}{|c|}{ Kegramatikalan } \\
\cline { 5 - 8 } & & & Pembentukan Kata & \multicolumn{2}{|c|}{ Penyusunan Kalimat } \\
\cline { 5 - 8 } & & & Afiksasi & $\begin{array}{c}\text { Redupli- } \\
\text { kasi }\end{array}$ & $\begin{array}{c}\text { Fungsi } \\
\text { Kalimat }\end{array}$ & $\begin{array}{c}\text { Penggabungan } \\
\text { Kalimat }\end{array}$ \\
\hline Jumlah & 26 & 42 & 43 & 8 & 1 & 35 & 31 \\
\hline Persentase & $50,9 \%$ & $82,3 \%$ & $84,3 \%$ & $15,6 \%$ & $1,9 \%$ & $68,6 \%$ & $60,7 \%$ \\
\hline
\end{tabular}

Berdasarkan tabel di atas, dapat dilihat bahwa dari sejumlah 51 kalimat yang tidak efektif, terdapat 26 kalimat yang tidak memenuhi aspek kelugasan $(50,9 \%), 42$ kalimat yang tidak memenuhi aspek kebernalaran $(82,3 \%)$, serta 43 kalimat yang tidak memenuhi aspek kepaduan $(84,3 \%)$. Sementara itu, berdasarkan aspek kegramatikalan dari segi pembentukan kalimatnya, diperoleh 8 kalimat dengan pembentukan afiksasi yang kurang baik $(15,6 \%)$ dan 1 kalimat dengan pembentukan reduplikasi yang kurang baik $(1,9 \%)$. Kemudian, berdasarkan aspek kegramatikalan dari segi penyusunan kalimatnya, terdapat 35 kalimat dengan penyusunan fungsi yang kurang baik $(68,6 \%)$ dari 31 kalimat dengan penggabungan kalimat yang kurang baik $(60,7 \%)$. Berdasarkan hasil analisis di atas, dapat diinterpretasikan bahwa dari keseluruhan data yang diambil dari skripsi mahasiswa Jurusan PGSD FIP UNJ di tahun 2012, terdapat lebih banyak kalimat yang efektif $(69,1 \%)$ dari pada kalimat yang tidak efektif (30,9\%). Kalimat efektif pada skripsi mahasiswa tersebut mencapai sekitar $70 \%$, artinya keefektifan kalimat dalam skripsi mahasiswa dapat dikatakan cukup baik.

Dalam kalimat yang efektif tersebut, aspek kalimat efektif yang paling banyak terpenuhi ialah aspek kegramatikalan dalam pembentukan kata dengan afiksasi $(99,1 \%)$, diikuti oleh aspek kegramatikalan lain yaitu dalam penyusunan kalimat berdasarkan fungsi kalimatnya (96,5\%). Hal ini menunjukkn bahwa aspek kegramatikalan memegang peranan yang sangat penting dalam pembentukan kalimat efektif. Kemudian, di posisi ketiga aspek kepaduan memperlihatkan persentase yang sama dengan aspek kegramatikalan dalam penyusunan kalimat dari segi penggabungan kalimatnya $(95,6 \%)$, diikuti oleh aspek kebernalaran $(92,1 \%)$ dan aspek kelugasan $(87,7 \%)$. Selanjutnya, aspek kegramatikalan dalam pembentukan kata dengan reduplikasi menjadi kemunculan paling sedikit $(16,6 \%)$ karena tidak setiap kalimat mengandung reduplikasi srhingga aspek ini tidak dapat diperhitungkan. Hal ini menunjukkan bahwa kalimat efektif dalam skripsi mahasiswa jurusan PGSD FIP UNJ dihasilkan oleh terpenuhinya aspek kegramatikalan.

Sementara itu, dalam skripsi mahasiswa FIP UNJ juga terdapat kalimat yang tidak efektif $(30,9 \%)$. Dalam kalimat yang tidak efektif tersebut, aspek kalimat efektif yang paling banyak tidak terpenuhi ialah aspek kepaduan (84,3\%), diikuti oleh aspek kebernalaran $(82,3 \%)$. Kemudian, aspek kegramatikalan dalam penyusunan kalimat dari fungsi kalimat $(68,6 \%)$ dan penggabungan kalimat $(60,7 \%)$ menempati urutan ketiga dan keempat yang diikuti oleh aspek kelugasan $(50,9 \%)$. Selanjutnya, aspek kegramatikalan dalam pembentukan kata dengan afiksasi $(15,6 \%)$ dan reduplikasi $(1,9 \%)$ menjadi 
kemunculan paling sedikit. Hal ini menunjukkan bahwa tidak terpenuhinya aspek kepaduan dan kebernalaran menjadi faktor utama penyebab kalimat tidak efektif dalam skripsi mahasiswa jurusan PGSD FIP UNJ, sedangkan tidak terpenuhinya aspek kegramatikalan dalam pembentukan kata menjadi faktor terkecil. Dengan demikian, dapat diartikan bahwa pemahaman mahasiswa dalam aspek kepaduan dan kebernalaran masih lemah.

\section{KESIMPULAN}

Penelitian ini menganalisis keefektifan kalimat pada skripsi mahasiswa jurusan PGSD FIP UNJ tahun 2012. Data penelitian ini ialah kalimat dalam skripsi mahasiswa pada bab latar belakang, pembahasan, dan kesimpulan yang direduksi hingga didapatlah 165 kalimat untuk dianalisis. Analisis data tersebut dilakukan berdasarkan aspek-aspek keefektifan kalimat, yaitu aspek kelugasan, kebernalaran, kepaduan, dan kegramatikalan kalimat. Dari hasil analisis tersebut didapatlah jumlah kalimat yang efektif dan kalimat yang tidak efektif. Dari 165 kalimat yang dianalisis, ditemukan 114 kalimat yang efektif dan 51 kalimat yang tidak efektif dari data yang dianalisis. Berdasarkan jumlah tersebut maka diperoleh persentase sebesar $69,1 \%$ dari seluruh data merupakan kalimat efektif dan $30,9 \%$ dari seluruh data merupakan kalimat tidak efektif.

Dalam kalimat yang efektif tersebut, aspek kalimat efektif yang paling banyak terpenuhi ialah aspek kegramatikalan dalam pembentukan kata dengan afiksasi (99,1\%), diikuti oleh aspek kegramatikalan dalam penyusunan kalimat berdasarkan fungsi kalimatnya (96,5\%). Hal ini menunjukkn bahwa aspek kegramatikalan memegang peranan yang sangat penting dalam pembentukan kalimat efektif. Sementara itu, dalam kalimat yang tidak efektif $(30,9 \%)$, aspek kalimat efektif yang paling banyak tidak terpenuhi ialah aspek kepaduan $(84,3 \%)$ sedangkan aspek kegramatikalan dalam pembentukan kata dengan afiksasi $(15,6 \%)$ dan reduplikasi $(1,9 \%)$ menjadi kemunculan paling sedikit. Hal ini menunjukkan bahwa tidak terpenuhinya aspek kepaduan menjadi faktor utama penyebab kalimat tidak efektif dalam skripsi mahasiswa FIP UNJ, sedangkan tidak terpenuhinya aspek kegramatikalan dalam pembentukan kata menjadi faktor terkecil. Berdasarkan hasil tersebut, dapat disimpulkan bahwa skripsi mahasiswa FIP UNJ terdiri atas kalimat efektif dan kalimat tidak efektif. Keefektifan kalimat tersebut dibangun atas berbagai aspek. Aspek yang paling menentukan dalam pembentukan kalimat efektif adalah aspek kegramatikalan. Oleh sebab itu, sebuah tulisan ilmiah harus memenuhi syarat kegramatikalan agar terbentuk keefektifan kalimat.

Saran yang ingin peneliti sampaikan mengenai penelitian ini ditujukan kepada mahasiswa yang membuat karya tulis ilmiah berupa skripsi, untuk memperhatikan keefektifan kalimat. Keefektifan kalimat ini berguna dalam penyampaian gagasan dari penulis kepada pembaca agar maksud yang diterima pembaca sesuai dengan maksud yang hendak disampaikan penulis. Selain itu, pemahaman mahasiswa mengenai kewacanaan yang menyangkut kepaduan dan kebernalaran kalimat dalam mata kuliah Bahasa Indonesia harus ditingkatkan berdasar pada hasil penelitian yang menunjukkan lemahnya pemahaman mahasiswa dalam hal tersebut. Kemudian, berdasarkan keterbatasan dalam penelitian ini, maka diharapkan peneliti selanjutnya dapat mengembangkan penelitian yang berkaitan dengan keefektifan kalimat dalam karya ilmiah mahasiswa berbentuk makalah penelitian. 
Arkhais, Vol. 06 No. 2 Juli - Desember 2015

\section{DAFTAR RUJUKAN}

Akhdiah, Sabarti dkk. 1991. Pembinaan Kemampuan Menulis Bahasa Indonesia. Jakarta: Penerbit Erlangga

Alwi, Hasan dkk. 2003. Tata Bahasa Baku Bahasa Indonesia. Jakarta: Balai Pustaka.

Arifin, E. Zaenal. 2006. Dasar-dasar Penulisan Karya Ilmiah. Jakarta: PT. Grasindo.

Badudu, J. S. 1994. Inilah Bahasa Indonesia yang Benar II. Jakarta: PT. Gramedia Pustaka Utama.

Chaer, Abdul dan Agustina, Leonie. 2004. Sosiolinguistik: Pengenalan awal. Jakarta: PT. Rineka Cipta.

Chaer, Abdul. 2011. Ragam Bahasa Ilmiah. Jakarta: PT. Rineka Cipta.

Jalal, Moch. 2012. "Problematika Kesalahan Bahasa pada Penulisan Skripsi Mahasiswa Universitas Airlangga.” Dalam Jurnal Ilmu Humaniora, Vol. 12, No.2.

Kalidjernih, Freddy K. 2010. Penulisan Akademik. Bandung: Widya Aksara Press.

Kridalaksana, Harimurti. 2007. Kelas Kata dalam Bahasa Indonesia. Jakarta: PT. Gramedia Pustaka Utama.

Kusumana, Suherli. 2010. Merancang Karya Tulis Ilmiah. Bandung: PT. Remaja Rosdakarya.

Ramlan. 1986. Ilmu Bahasa Indonesia "Sintaksis”. Yogyakarta: Cv. Karyono.

Santoso, K. Budi. 1990. Problematika Bahasa Indonesia. Jakarta: Rineka Cipta.

Semi, M. Atar. 2003. Menulis Efektif. Padang: Percetakan Angkasa Raya.

Soedjito. 1986. Kalimat Efektif. Bandung: Remadja Karya CV.

Sugono, Dendy (Ed.). 2008. Buku Praktis Bahasa Indonesia. Jakarta: Pusat Pembinaan dan Pengembangan Bahasa.

. 2009. Mahir Berbahasa Indonesia dengan Benar. Jakarta: PT. Gramedia Pustaka Utama.

. 2012. "Kaidah Bahasa Indonesia dalam Karya Tulis Ilmiah", dalam PembinaanTeknis Penulisan Karya Ilmiah. Pusat Penelitian Kebijakan, Balitbang, KemdikbudCiawi.

Hamid, Farid dan Rachman, A. "Buku Panduan Skripsi" dalam http://id.wikipedia.org/wiki/skripsi

Murad, Abdul. "Analisis Pemakaian Bahasa Ilmiah Skripsi Mahasiswa" dalam http://lppm.uisu.ac.id

Sukarmin, Yustinus. "Identifikasi Kesalahan Penyusunan Skripsi Mini dalam Mata Kuliah Penulisan Karya Ilmiah Mahasiswa Fakultas Ilmu Keolahragaan" dalam http://staff.uny.ac.id 